Tomasz Maria Dąbek OSB

\title{
Śp. o. prof. dr hab. Augustyn Jankowski OSB i Biblia Tysiąclecia
}

Na temat powstania Biblii Tysiaclecia można przeczytać własne słowa jej zmarłego redaktora w książce, do powstania której przyczynił się jego ostatni doktor ks. Wiesław Alicki razem z Januszem Jabłońskim oraz Anną i Markiem Łosiami $^{1}$. Sa to rozmowy przeprowadzane najpierw dla radia, a potem do wydania w formie książki (Nikt z nas nie żyje dla siebie... Z o. Augustynem Jankowskim OSB rozmawiaja ks. Wiesław Alicki, Janusz Jabłoński, Anna i Marek Łosiowie, Kraków 2005). Dzięki temu mamy jakby jego żywy głos odpowiadający na pytania w wielu sprawach ciekawych nie tylko z punktu widzenia jego osobistego życia i pracy naukowej, ale w ogóle nauki i Kościoła.

W związku z projektem Biblii Tysiąclecia o. Jankowski mówi: „Redaktorem zostałem dlatego, że tak sobie życzył seniorat naszego opactwa”. Już w tych słowach widać wielką skromność - nikt inny w Tyńcu nie byłby zdolny do przeprowadzenia takiej pracy. Tylko on miał odpowiednie studia, imponował wspaniałą znajomością Biblii, potrafił od razu podać miejsca występowania bardzo wielu tekstów.

Pomysł zrodził się, gdy ktoś ze współbraci z jednej z bardzo wtedy rzadkich podróży zagranicznych przywiózł małego formatu francuską Biblię Jerozolimska. Projekt nowego przekładu z języków oryginalnych na współczesny polski język literacki bez archaizmów przedstawił o. Jankowski na sympozjum biblistów, mówiąc, że właśnie KUL powinien go wydać, kontynuując tradycje rozpoczęte przez ks. Kruszyńskiego. Dał pół roku na podjęcie decyzji: jeśli nie KUL, to Tyniec był gotów prowadzić dzieło, koordynując pracę ponad czterdziestu biblistów. Początkowo wydawało się, że praca zajmie około dwóch lat. Trwała sześć. Udało się jednak przygotować publikację przed millennium chrztu Polski i w roku 1965 kard. Wyszyński wręczył nowy przekład Pawłowi VI.

${ }^{1}$ Wspomnienie przedstawione podczas międzynarodowej sesji naukowej dla uczczenia 40. rocznicy soborowej konstytucji Dei Verbum i polskiego przekładu Biblii Tysiąclecia (Kraków, 17 listopada 2005). 
Wśród tłumaczy byli zarówno doświadczeni bibliści, jak też początkujący wykładowcy. Nieraz zarzucano, że niektóre teksty są bardziej przekładami z Biblii Jerozolimskiej niż oryginału hebrajskiego. O. Jankowski nie mógł sam wszystkiego zmienić, szanował pracę innych. Sam bardzo sumienny i dokładny, wymagał wiele od siebie; uważał, że inni postępują podobnie. Ingerował tylko w ważnych wypadkach.

Redakcja i koordynacja całości była pracą ogromną. O. Jankowski wspomina współpracowników zarówno chętnie przyjmujących propozycje zmian, jak też (bez wymieniania nazwisk żyjących) tych, którzy mocno stali przy swoich pierwotnych wersjach.

W skład Tynieckiego Kolegium Redakcyjnego czy Adiustacyjnego (tak nazwanego we wstępie II wydania) wchodzili ludzie z różnym przygotowaniem naukowym. O. Piotr Rostworowski przed wojną rozpoczął studia na Biblicum, znał dobrze język hebrajski i przełożył w Biblii Tysiąclecia Pieśń nad pieśniami oraz opracował do niej komentarz. Jego studia przerwano w związku z fundacją w Tyńcu. Jako mnich nie publikował tekstów naukowych, działał głównie jako rekolekcjonista i kierownik duchowy wielu osób. Znany liturgista o. Franciszek Małaczyński znał dobrze łacinę oraz liturgię Kościoła. O. Józef Hajduga był pierwszym, który odbył nowicjat w Polsce po powrocie benedyktynów do Tyńca. Pochodził z Kaszowa z drugiej strony Wisły w parafii Liszki. Na początku XX wieku ukończył gimnazjum św. Anny w Krakowie i prawo na Uniwersytecie Jegiellońskim, w czasie I wojny światowej był oficerem, jego były ordynans pochodził z Tyńca i potem jako krawiec szył nam habity. Po wojnie dr Hajduga ukończył teologię, jako kapłan był notariuszem Kurii Krakowskiej, a w 1940 roku wstąpił do benedyktynów. Choć znał doskonale łacinę, bardzo sobie cenił możliwość odmawiania Liturgii godzin w języku polskim. Kiedy nie mógł już chodzić do kościoła, nowicjusze przynosili mu do celi na określony czas, kiedy odmawiał Godzinę czytań, jedyny wówczas egzemplarz przekładu drugiego czytania. Pomagali też pierwszy doktor o. Augustyna o. Ludwik Mycielski, o. Karol Meissner, ale również i zwyczajni współbracia, zdolni raczej do pomocniczych prac, np. korekt polegających na sprawdzaniu ze wzorem, niż do twórczej krytyki i merytorycznych poprawek.

O. Jankowski sam przełożył listy więzienne św. Pawła oraz Apokalipsę. Jako tłumacze Psałterza podani są w I wydaniu Benedyktyni Tynieccy. Było to tłumaczenie nie $\mathrm{z}$ oryginału, ale z pięknego łacińskiego przekładu dokonanego podczas wojny z inicjatywy Piusa XII przez profesorów Papieskiego Instytutu Biblijnego pod kierunkiem o. prof. A. Bea, późniejszego kardynała. Do drugiego wydania miał przełożyć Księgę Psalmów z języka hebrajskiego Roman Brandstaetter, ale nie udało się skłonić go do przyjęcia naukowych 
kryteriów, m.in. jednakowego tłumaczenia tego samego terminu hebrajskiego. Uważał, że jako Żyd i poeta lepiej rozumie tekst niż akademiccy uczeni. Dlatego jego pracę wydał PAX, a w II wydaniu znalazł się przekład dokonany przez o. Augustyna Jankowskiego i ks. Lecha Stachowiaka.

O. Jankowski pisze też o krytyce, z jaką spotkała się Biblia Tysiąclecia, przede wszystkim ze strony jego dawnego mistrza ks. prof. Eugeniusza Dąbrowskiego. Był pierwszym polskim doktorem nauk biblijnych, bardzo zasłużonym w propagowaniu spraw biblijnych (jako dziecko i uczeń szkoły średniej kilkakrotnie dostawałem różne wydania jego przekładów Ewangelii i całego Nowego Testamentu z Wulgaty albo z greki w namaszczonym języku zbliżonym do przekładu o. Jakuba Wujka), ale stojącym na pozycjach tradycyjnych, z czasów swoich rzymskich studiów w okresie międzywojennym,

Kiedy przyszedłem do Tyńca latem 1971 roku, rozpoczynało się wspólne odmawianie niektórych części Liturgii godzin w języku polskim. Korzystano z psałterza I wydania Biblii Tysiąclecia. Jeśli porównać go z obecnie używanym w liturgii opracowaniem Marka Skwarnickiego, można dostrzec bardzo niewiele różnic, głównie stylistycznych.

Drugie wydanie nosi datę 1971. Trzeba jednak pamiętać o warunkach drukowania katolickich książek w czasach komunistycznych, kiedy władza zatwierdzała plan wydawniczy i książki musiały nosić zgodne z nim daty, choć faktycznie niekiedy ukazywały się znacznie później. Teksty do korekty drugiego wydania Biblii Tysiąclecia przyszły do Tyńca w zimie 1971/1972. Jako nowicjusz również otrzymałem pewne partie do przeczytania. Wśród zmian w stosunku do pierwszego wydania chyba najważniejszy był naukowy przekład Księgi Psalmów, pewna ilość poprawek merytorycznych oraz wiele korekt językowych. Niektóre były dyskusyjne, np. przetłumaczenie remeś (np. Rdz 1, 24) oddawanego dawniej zwykle jako „płazy” przez „,zwierzątka naziemne” (w wydaniu piątym - „zwierzęta pełzające”). Szczególnie humorystycznie brzmiało to np. w Oz 2, 20: „Zawrę przymierze [...] ze zwierzątkiem naziemnym".

Jako kleryk, kiedy mogłem w większym stopniu dysponować swoim czasem, widziałem, że o. Augustyn nie ma jakiegoś stałego współpracownika, i starałem się w miarę możności mu pomagać, zwłaszcza przepisując na maszynie poprawki do Biblii Tysiąclecia (między II a III wydaniem). Wykaz zajął ok. 100 stron maszynopisu z odstępem półtorawierszowym, czyli ok. 40 wierszy na stronę, zatem poprawek było ok. 3 tysięcy. Ks. prof. Eugeniusz Dąbrowski nazwał Biblię Tysiąclecia „Biblią tysiąca błędów i pomyłek”. Jeśli się pamięta, że w czasach, gdy nie było komputerów, w tekście maszynopisu tolerowano 5 poprawek na stronę (zapisaną z podwójnym odstępem, zawierającą ok. 2 tys. znaków), to Biblia Tysiąclecia licząca blisko 1,5 tys. stron zadrukowanych 
czcionką małego formatu, jeśli miała nawet tysiąc błędów, to było ich o wiele mniej, nawet wielokrotnie mniej, niż wtedy normalnie dopuszczano.

Kiedy studiowałem, przez blisko 10 lat Ojciec Profesor mówił studentom, że następne wydanie Biblii Tysiąclecia ukaże się w najbliższym czasie. Znowu opierało się to na przekonaniu, że Wydawnictwo Pallottinum będzie się starało jak najszybciej dostarczyć najlepszą możliwą wersję. Jednak działało ono już wtedy bardziej jak firma komercyjna, drukując najpierw to, co przynosi większy zysk, i wykorzystując na dodruki wcześniej przygotowane materiały dawniejszego wydania.

Wydanie trzecie ma na karcie tytułowej podany rok 1980, czwarte było jego niezmienioną kopią. Trochę zmian wprowadzono do piątego, które też długo czekało na druk, a nawet było sprzedawane równolegle z poprzednim. Obok potrzebnych zmian merytorycznych wprowadzono także stylistyczne, niektóre chyba zbędne, np. w Kol 3, 14: „miłość [...] jest spoiwem doskonałości”. Wcześniej było „więzią” - obie formy są bliskoznaczne i do przyjęcia. Gdyby od początku było „spoiwo”, nie trzeba by wprowadzać zmiany, choć może ono kojarzyć się z różnymi materiałami, jak np. wosk lub kit. W 1 P 3, 20 dziwaczna forma „naczekiwała” zamiast „oczekiwała”. Nowi redaktorzy, których fachowe przygotowanie jako polonistów o. Jankowski szanował, też chcieli zaistnieć również wtedy, gdy zmiany nie były potrzebne, ale propozycje były co najmniej dyskusyjne z punktu widzenia wyczucia języka, różnego w różnych regionach Polski.

Ze względu na swoje zaangażowanie w sprawy klasztorne i duszpasterskie nie współpracowałem przy kolejnych wydaniach, każde jednak uważnie przeczytałem i przekazałem swoje uwagi o. Jankowskiemu, który zawsze chętnie je przyjmował, rozważał i był gotów do wprowadzenia uzasadnionych zmian. Dokładnie czytał wszystkie listy przynoszące słowa krytyki i nowe propozycje.

Oczywiście Biblia Tysiąclecia nie jest doskonałym tłumaczeniem. Często młodzi bibliści krytykują ją, używając ogólnych sformułowań, zwykle bez pokazywania konkretnych niedociągnięć. Najlepszą odpowiedzią jest zachęta skierowana do takiego krytyka, by przetłumaczył choć jedną księgę i wydał ją z krótkim komentarzem - im więcej będzie przekładów w naszym języku, tym lepiej.

Ojciec Jankowski do końca był czynny, planował dalsze prace i nowe wydania wcześniejszych monografii. Chętnie służył pomocą duchową, wiele osób korzystało z jego kierownictwa. Do klasztorów garną się ludzie potrzebujący, by ktoś ich wysłuchał, doradził. Nieraz nie bardzo widać, by dobre rady przynosiły od razu poważniejsze zmiany. Kiedyś, gdy nie było mistrza duchowego takiej osoby (nie był nim o. Jankowski), ktoś go zastąpił. Na pytanie, co jest 
jej najbardziej potrzebne do postępu wewnętrznego, odpowiedział: „Rzucić palenie!”. Więcej „dusza” nie prosiła go o rady i pomoc.

W ostatnich miesiącach było widać, że o. Augustyn ma coraz mniej sił. Uczestniczył we wszystkich zajęciach wspólnoty, na koncelebrę dopiero w ostatnich dniach ubierał się w małej zakrystii blisko ołtarza, wcześniej szedł kilkadziesiąt metrów i po powrocie ciężko opierał się o stół zakrystii. Wyznaczano mu miejsce przy ołtarzu, aby mógł się o niego oprzeć. Nie chciał jednak żadnych przywilejów. Kiedy mu zaproponowano, by podpierał się laską, jak młodszy o siedem lat współbrat, odpowiedział, że póki może, woli chodzić bez podparcia.

Dużym ułatwieniem była dla niego winda zainstalowana podczas wakacji w budynku Papieskiej Akademii Teologicznej przy ul. Franciszkańskiej w Krakowie. W czwartek ostatniego tygodnia życia jeszcze prowadził wykład, w piątek czuł się słabo, wydawało się, że to dolegliwości żołądkowe. W nocy poprosił o sakrament chorych. W sobotę przyszedł na jutrznię i koncelebrował mszę świętą, choć już chwilami nie mógł stać. Lekarz zalecił leczenie w szpitalu. Tam stwierdzono wcześniejszy zawał serca, który objawiał się nie silnym bólem, ale nudnościami i ogólnym osłabieniem. Po południu jeszcze w rozmowie żartował, w niedzielę rano odmówił jutrznię i pytał o możliwość celebracji mszy św. O godzinie 7.15 ustała praca serca i nie udało się jej przywrócić.

Pan oszczędził mu długich cierpień i braku sprawności. Ufamy, że jak z wielką życzliwością odnosił się do wszystkich w ciągu ziemskiego życia, tak teraz wyprasza nam potrzebne łaski, a jego przykład wzywa nas do skromności, solidności, wielkoduszności i gorliwości w podejmowaniu i doprowadzaniu do końca prac potrzebnych dla sprawy Bożej, Kościoła i ludzi. 


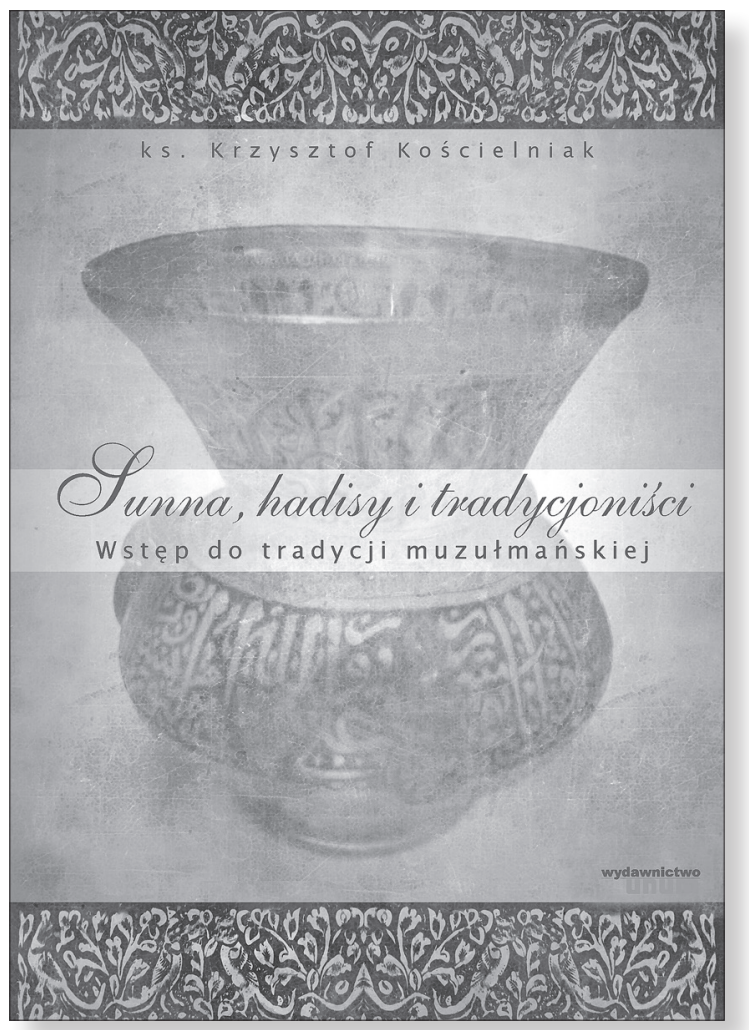

\title{
Nowość!
}

ks. Krzysztof Kościelniak

\section{Sunna, hadisy i tradycjoniści}

\author{
WSTEP DO TRADYCJI \\ MUZUUMAŃSKIEJ
}

141 stron $\cdot$ format $14,5 \times 20,5 \mathrm{~mm}$
oprawa broszurowa $\cdot$ cena $\mathbf{1 9} \mathbf{z t}$

Hadisy są drugim po Koranie spisanym źródłem teologii muzułmańskiej. Zawierają one wypowiedzi Mahometa, opowiadania, relacje czy przypowieści na temat jego życia. Hadisy są „nośnikami” tradycji muzułmańskiej i mają zarówno charakter religijny, jak również prawny i etyczny. Tworzą one tzw. sunnę, czyli „ścieżkę Mahometa”, którą winna kierować się cała umma - „społeczność muzułmańska”.

Islam sunnicki przywiązuje do tradycji tak wielką wagę, że o sunnitach zwykło mówić się jako o „ludziach tradycji i wspólnoty”. Zdaniem sunnitów każdy muzułmanin powinien poprawiać całe swoje życie w świetle sunny nawet w najmniejszych detalach, aby uchronić się przed jakimikolwiek nagannymi innowacjami religijnymi. W konsekwencji tradycja muzułmańska z jednej strony przedstawia i wciela w praktykę przepisy koraniczne, z drugiej strony zaś sama w sobie stanowi źródło dogmatów i moralności. Już w VIII wieku Koran i sunna zostały zrównane co do ważności, a specjaliści od hadisów szybko uznali siebie za znawców prawa, teologów, egzegetów i specjalistów czytania Koranu.

Książka Sunna, hadisy i tradycjoniści wprowadza czytelnika w świat tradycji islamskiej, omawia aspekty etymologiczne i historię sunny Proroka oraz znaczenie hadisów w muzułmańskich klasycznych szkołach teologiczno-prawniczych, prezentuje islamskie metody weryfikacji tradycji, ukazuje różne aspekty prowadzonej od lat dyskusji naukowej wśród orientalistów i teologów muzułmańskich na temat prawdziwości hadisów.

Publikacja została zainspirowana zachodnimi introdukcjami do sunny i jest próbą wypełnienia luki na temat tradycji muzułmańskiej w literaturze polskiej. Intencją autora jest, aby niniejsza praca stała się podręcznym wprowadzeniem zawierającym podstawowe zagadnienia związane z tradycją muzułmańską wraz z podstawową bibliografią.

\section{Zamówienia}

Wydawnictwo UNUM · ul. Kanonicza 3 · 31-002 Kraków tel. (12) $4225690 \cdot$ e-mail: unum@ptt.net.pl

Koszt przesyłki ponosi wydawnictwo. 